\title{
Using LEGO MINDSTORMS in Primary Schools: Perspective of Educational Sector
}

\author{
https://doi.org/10.3991/ijoe.v18i01.27579 \\ Khawla Nasser AlQarzaie ${ }^{(凶)}$, Sara Awadh AlEnezi \\ Qassim University, Buraydah, Saudi Arabia \\ kn.alqarzaie@qu.edu.sa
}

\begin{abstract}
Programming is a great means for kids to learn different skills such as logical thinking and problem solving. LEGO MINDSTORMS This study explores the readiness and viability of teaching program-ming schools in Saudi primary schools using LEGO MINDSTORMS.LEGO MINDSTORM was chosen as it is a good tool for LEGO MINDSTORMS playing and education. This study conducted a survey to investigate the opinions of education officials and education managers toward the viability of using LEGO MINDSTORMS to teach students programming concepts in primary schools. The samples were from the ministry of education. The ministry's members gave recommendations on how LEGO MINDSTORMS can be introduced to the primary school students and identified some of the obstacles that may delay this process. Based on the survey. The survey results showed that more than half of the members agree that primary school students should introduce programming skills. The results also showed that most of them prefer Scratch software over LEGO MINDSTORM to teach programming.
\end{abstract}

Keywords-LEGO MINDSTORMS, programming teaching, children

\section{$1 \quad$ Introduction}

Today, we live in a new and changing digital world, and information technology becomes part of everyone's lives, including children. Itis believed that programming learning should be introduced to children in the early stages of their education [1,2]. Learning and playing are related to each other, especially for children. Playing is fun for children, but at the same time, it represents one of the ways they actually learn from [3-6].

There are many programming platforms attractive to children to play with, such as Scratch [7], Alice [8], Blockly [7], and LEGO MINDSTORMS [9]. These platforms can be used to teach children programming and logical thinking in general.

- Scratch: Jump-start future programmers with adaptive sandbox tool [10].

- Codemoji: Emoji-based coding tool that demystifies web design and animation design.

- Evo by Ozobot: flexible little robot specially made for teaching coding [11]. 
- Cozmo: A mini robot with big characters brings code to life [12].

- SAM Edu, Tickle, and more.

There are some private centers in Saudi Arabia that use LEGO MINDSTORMS in programming teaching, but there is not used in schools of Saudi Arabia.

- Bricks 4 Kidz ${ }^{\circledR}$ : A Bricks 4 Kidz ${ }^{\circledR}$ field trip takes learning out of the pages of the textbook and into an imaginative, 3-dimensional, hands-on learning knowledge! Using the LEGO® bricks, your students already know and love to get them excited about learning. "A Bricks $4 \mathrm{Kidz}{ }^{\circledR}$ field trip is a fun-filled, engaging experience that kids will be talking about long after the fun and learning have ended"[13]. Camps of Bricks 4 Kidz® are held in Riyadh and Al Jubail.

- First Lego League: Guided by adult Coaches, FIRST LEGO League teams explore real-world problems such as food safety, recycling, energy, etc., and are challenged to improve a solution. They also should design, build, pro-gram a robot by using LEGO MINDSTORMS $®$ technology, then compete on a table-top playing field. The helpful effect FIRST LEGO League has on participants is interesting and well documented. More than $88 \%$ are more interested in doing well in school, and $87 \%$ have more interest in attending college. It is a center in Riyadh, and it has 29000 robots [14].

- Robot Club in AlQatif: Robot Club is the first scientific club that specialized in robotics (robot) in Qatif city. The idea of establishing the club was started in 2007 by its founder, Hussein bin Abdullah Al-Mohsen. The first courses began in the design and programming of the robot in 2008 after the acceptance of Huda Club on the island of Tarot to host the project and with the support of SAP (SAP), which has imported the model (LEGO MINDSTORMS NXT 2.0), which is one of the best models in the teaching and simplifying the robot science [15].

- Arabic Robot Center: Arabic robot is a website as an online center to learn how to program robots. It aims in the near future to open an Arabic lab contains Arabic professional programmers [16].

Using a survey, this study attempts to get the opinions of people in the Saudi educational sector about starting programming teaching at an early stage, i.e., in the primary grade. The respondents were all members of the computer science department in the ministry of education in Saudi Arabia. The study proposes LEGO MINDSTORMS EV3 for teaching programming in primary schools. LEGO MINDSTORMS is a product of the toy manufacturer LEGO. It contains a programmable brick, a lot of sensors and motors and can be built up with the LEGO technical line [17]. It contains a flexible LEGO® brick system, combining with easy to use coding software and engaging STEM challenges. LEGO MINDSTORMS EV3 is one of the most popular and widely used robotics education kits in the world"[18]. It is LEGO set of robotic systems to comprise a programming language, a microchip, a wise brick, and Lego set items, like gears and cogwheels [18],[19],[20]. The robotic system additionally uses emblem, a pro-griming language that may operate in coordination with the Lego set items. Sensors, engines, Lego set items, and programmable bricks represent the idea of LEGO MINDSTORMS [18]. 
LEGO MINDSTORMS was selected as a tool for programming teaching for the following reasons [17], [18], [19]:

1. LEGO MINDSTORMS have the potential to greatly influence the nature of science and technology education at all levels, from kindergarten to university [21].

2. LEGO MINDSTORMS are also easy to use, easy to learn, and make the coding learning process more enjoyable [22].

3. LEGO MINDSTORMS kits have been used widely for programming teaching, especially for young people. $[9,21,23]$ found that the kits helped to understand and improve children's thinking skills, mathematics, science and the ability to understand how systems work [9, 21, 23]. In another study [18], it was indicated that the kit is effective for teaching machine thinking, downside determination, programming, teamwork and project management to elementary-level children.

4. LEGO MINDSTORMS enable children to explore coding through real-life problem solving and hands-on learning experiences [23-25].

\section{Related work}

According to N. C. Zygouris, A. Striftou, A. N. Dadaliaris, G. I. Stamoulis, A. C. Xenakis, and D. Vavougios [9] review of literature has exposed that Educational Robotics is a rising field with the possibility to considerably affect the nature of science and technology education at all levels, from kindergarten to university. Studies in the field of robotics have reported so as to robotics have a possible effect on the learning of students in several subject fields (Physics, Mathematics, Engineering, Informatics and etc.) [21]. In [2] Mindstorms could be a great and useful tool in process of educating pre-college and college-age students [10].In [1], Worked to build a small project to replicate all learned topics and to use a little algorithms [11].

In [24] Offered course to teach student between13-16 the programming language consist of 10 lectures that is 20 hours in two weeks [12].[21] The Ministry of Education in UAE has applied two main projects in public schools to prepare students with scientific skills and improve their innovative thought and creativity. Education Council supported the use of robotics in schools as an educational tool. The educational organizers are aware that robotics is a perfect platform for learning 21 st century skills. In 2008, the ministry made the organization of the World Robot Olympiad (WRO) in the United Arab Emirates [9].

In the study [3] behave a summer camp on teaching robotics using LEGO MINDSTORMS EV3 for elementary level children from 8 May 2016 to 17 May 2016 in Bangalore (India). [25] teaching and learning of Computer Science in engineering courses at the University of Applied Sciences Aschaffenburg the Lego Mind-storms EV3 robots were included into the practical lectures for an imitation of a LEGO MINDSTORMS EV3 robot that is used for teaching ANSI CIt has been established why an imitation is very important to develop the process of learning and teaching [15]. 


\section{Methodology}

This study used a survey method to know the opinions of education officials and managers toward the introduction of "LEGO MINDSTORMS as a tool for programming teaching" for primary school students as such. The respondents of the survey were members of the educational technology department at the ministry of education in Saudi Arabia. A random sampling technique was used to gather the data for the survey. Over 300 members have been invited to fill the survey. The survey is crosssectional, and it was online. The survey at-tempts to know respondents' opinions about using LEGO MINDSTORMS for programming teaching in primary school and the difficulties in applying this idea. The survey contains nine closed-ended questions (See Table 1). As shown in the table, some questions are about LEGO MINDSTORMS and others are about programming teaching for children in general. Together with the online survey questions, an overview of LEGO MINDSTORMS was provided to the respondents through a link to a YouTube video. Google forms were used to build the survey. The survey was open for one week.

In this section, we will introduce deep learning methods based on object detection, a comparative analysis of existing AI models, feedback of Saudi citizen about traffic safety then we list some basic challenges in video object tracking and requirements based on their features, after that we define the recommended solution that help to solve and reduce different problems.

Table 1. Survey Questions

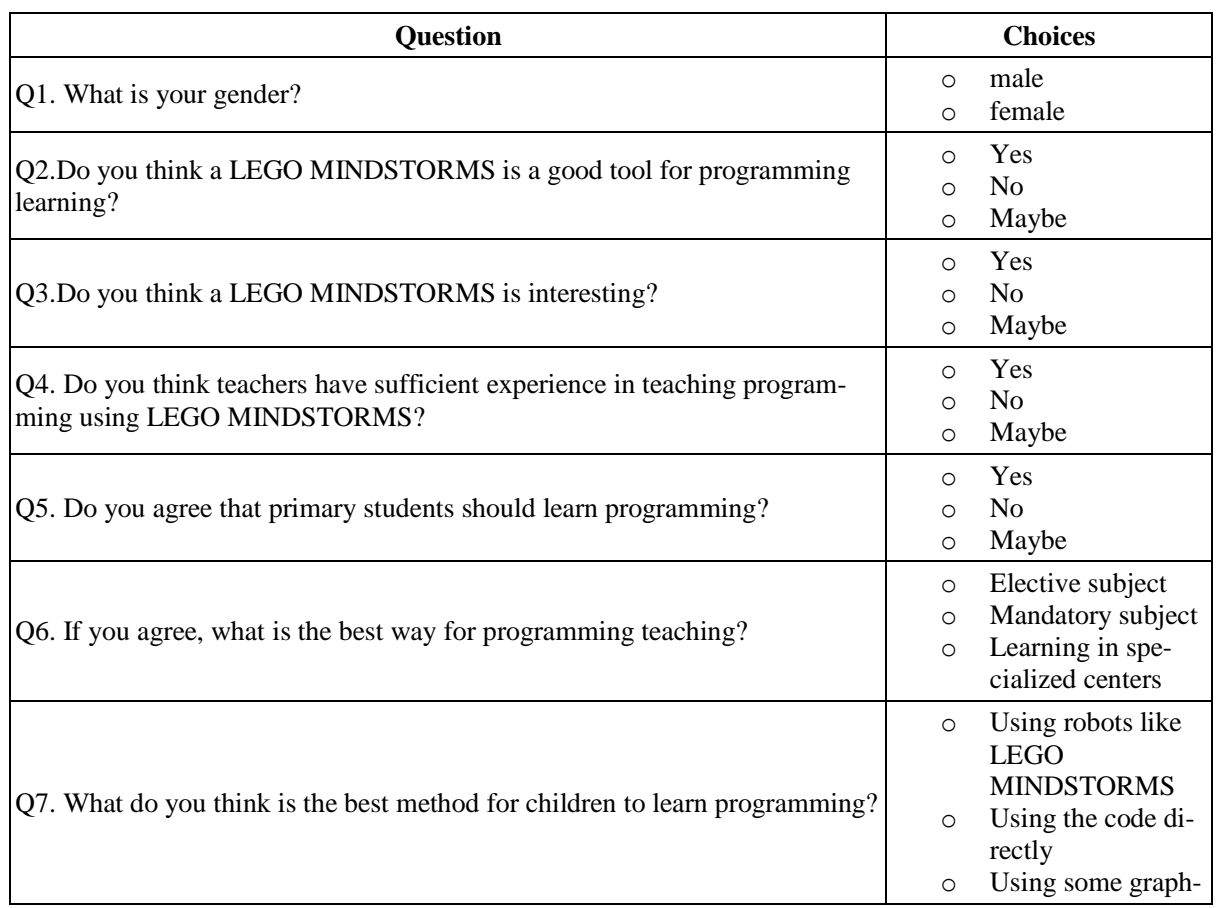




\begin{tabular}{|c|c|c|}
\hline & & $\begin{array}{l}\text { ical applications } \\
\text { and games (such as } \\
\text { Scratch) }\end{array}$ \\
\hline Q8. What grades are suitable for teaching programming? & 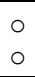 & $\begin{array}{l}\text { Grade } 1^{\text {st }} \text { to } 3^{\text {rd }} \\
\text { Grade } 4^{\text {th }} \text { to } 6^{\text {th }}\end{array}$ \\
\hline $\begin{array}{l}\text { Q9. What are the obstacles faced by the Ministry of Education in Saudi } \\
\text { Arabia to teach programming for children using LEGO MINDSTORMS? }\end{array}$ & ○ & $\begin{array}{l}\text { Labs are not avail- } \\
\text { able } \\
\text { Lack of experience } \\
\text { of teachers } \\
\text { High price of robot } \\
\text { Children cannot } \\
\text { learn programming } \\
\text { in this early stage } \\
\text { Others }\end{array}$ \\
\hline
\end{tabular}

\section{$4 \quad$ Results and discussion}

In total, 212 members responded to the survey, with a majority of females $(89.2 \%)$,

Interestingly, more than the half of the members $(67.9 \%)$ agreed that programming learning should be introduced to students in primary schools (See Figures 1 and 2) and Table 2.

\section{Gender}

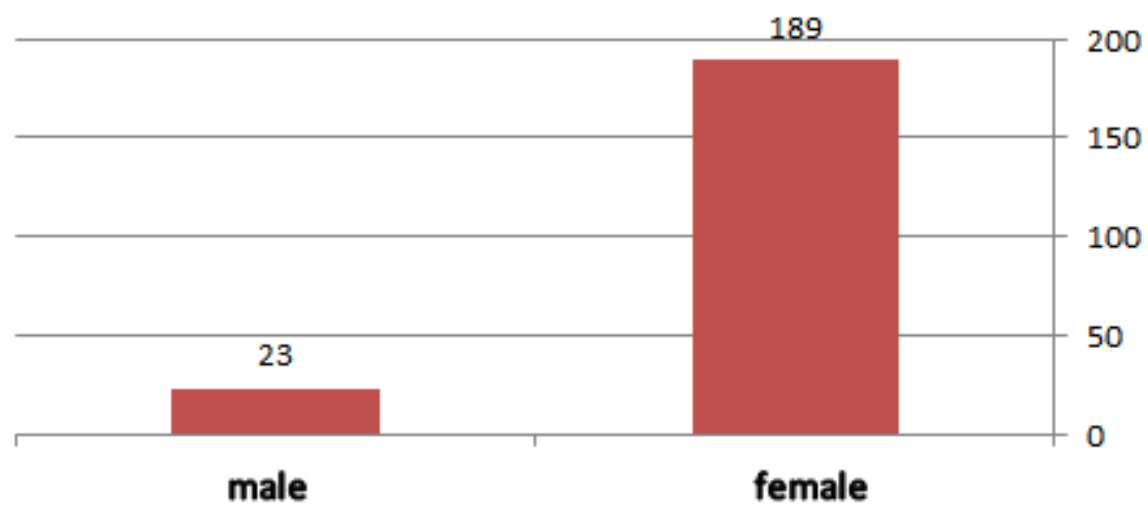

Fig. 1. Number of members' responses by gender 


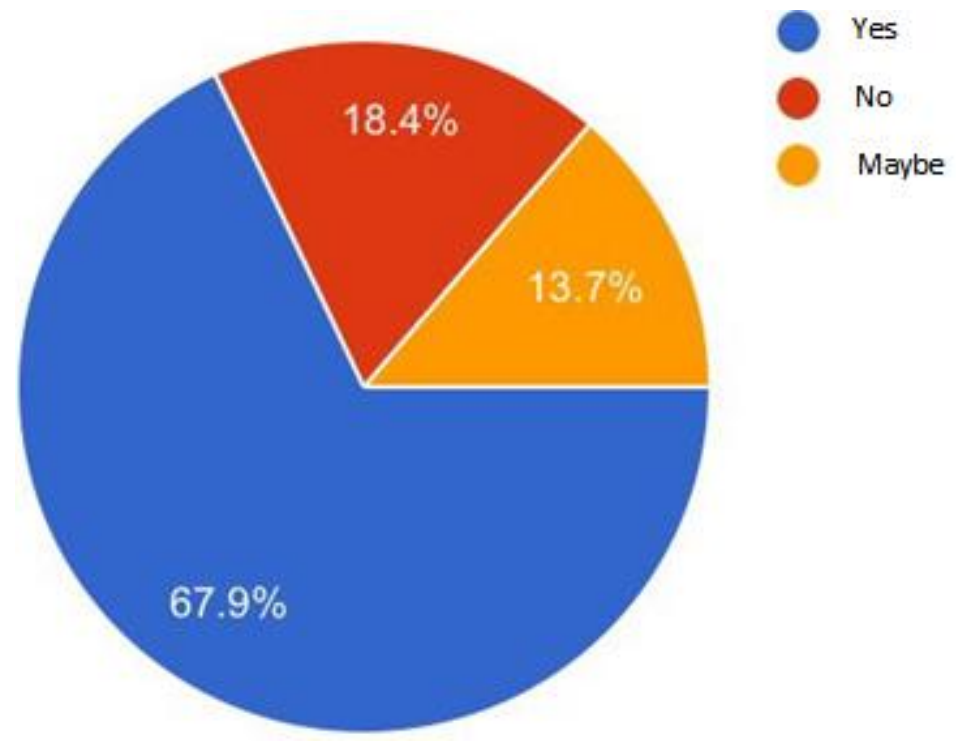

Fig. 2. Support programming learning in primary schools as the main course, not as an activity

Table 2. Survey responses

\begin{tabular}{|c|c|c|c|}
\hline Questions & Yes & No & Maybe \\
\hline $\begin{array}{l}\text { Do you think a LEGO MINDSTORMS is } \\
\text { interesting for student and teachers? }\end{array}$ & 57.1 & 7.1 & 35.8 \\
\hline $\begin{array}{l}\text { Do you think teachers have sufficient experi- } \\
\text { ence in learning programming using LEGO } \\
\text { MINDSTORMS? }\end{array}$ & 5 & 59.6 & 35.4 \\
\hline $\begin{array}{l}\text { Do you agree that primary students should learn } \\
\text { programming? }\end{array}$ & 67.9 & 18.4 & 13.7 \\
\hline $\begin{array}{l}\text { Do you think a LEGO MINDSTORMS is a } \\
\text { good tool for programming learning? }\end{array}$ & 52.4 & 3.7 & 43.9 \\
\hline \multirow{2}{*}{$\begin{array}{l}\text { What is the best way for programming teach- } \\
\text { ing? }\end{array}$} & Elective subject & $\begin{array}{c}\text { Mandatory } \\
\text { subject }\end{array}$ & $\begin{array}{l}\text { Learning in spe- } \\
\text { cialized centers }\end{array}$ \\
\hline & 48.1 & 33 & 18.9 \\
\hline \multirow{2}{*}{$\begin{array}{l}\text { What do you think is the best method for chil- } \\
\text { dren to learn programming? }\end{array}$} & $\begin{array}{l}\text { robots like LEGO } \\
\text { MINDSTORMS }\end{array}$ & code directly & $\begin{array}{l}\text { graphical applica- } \\
\text { tions and games }\end{array}$ \\
\hline & 24.1 & 7.5 & 68.4 \\
\hline \multirow{2}{*}{$\begin{array}{l}\text { What grades are suitable for teaching program- } \\
\text { ming? }\end{array}$} & Grade $1^{\text {st }}$ to $3^{\text {rd }}$ & \multicolumn{2}{|c|}{ Grade $4^{\text {th }}$ to $6^{\text {th }}$} \\
\hline & 23.6 & \multicolumn{2}{|r|}{76.4} \\
\hline
\end{tabular}

With regards to the LEGO MINDSTORMS as an interesting tool for teachers, about $57.1 \%$ of the respondents agree to that. About $59.4 \%$ of the teachers don't have experience in LEGO MINDSTORMS this is expected as LEGO MINDSTORMS is a new tool that they have not used before.

For programming should learning in the primary stage, about 67.9 think it is an important subject and take into consideration. Almost 52\% think a LEGO 
MINDSTORMS agree is a good tool for programming learning, but high percentage about $43 \%$ they have a doubt about this tool perhaps because of the difficulties that we will mention later. About $48 \%$ prefer to study programming as an elective subject. With regards to the best method for children to learn programming about $68.4 \%$ of the respondents accept using some graphical applications and games (such as Scratch). About $76.4 \%$ of respondents prefer that children study programming in grade 4th to 6th.

In Table 3 shows difficulties in using LEGO MINDSTORMS in primary schools. As shown, high percentage about $75 \%$ of the respondents think that the labs are not available, about $64 \%$ think lack of experience of teachers, about $45 \%$ of the respondents see children cannot learn programming in this early stage and almost $43 \%$ think high price of robot.

Table 3. Difficulties in using LEGO MINDSTORMS in primary schools

\begin{tabular}{|l|c|}
\hline \multicolumn{1}{|c|}{ Difficulty } & No. of responses \\
\hline Labs are not available & 75.5 \\
\hline Lack of experience of teachers & 64.6 \\
\hline High price of robot & 43.9 \\
\hline Children cannot learn programming in this early stage & 45 \\
\hline
\end{tabular}

\section{$5 \quad$ Conclusion and future work}

This paper conducted a survey for opinions about using LEGO MINDSTORMS for programming teaching in primary school and the difficulties in applying this idea around 200 participated to the survey. The results of the survey showed that people in the educational sector in Saudi Arabia do agree with the introduction of LEGO MINDSTORMS for teaching programming in primary schools. However, they have few difficulties such as labs are not available, lack of experience of teachers, the high price of robots and children, cannot learn programming in this early stage. More studies are needed to explore the perspectives of teachers and students in using LEGO MINDSTORMS as a tool for programming teaching in Saudi primary schools.

There are several aspects that can be improved in order to make future research on this topic more accurate and more meaningful. In the future it is planned to conduct real experiments on primary students using LEGO MINDSTORMS and Scratch. Students do several tasks on each of them and use programming to solve several tasks. And then we observe the student's interaction for each one of them and compare which one will impress the students more and achieve the highest response.

\section{References}

[1] Perez, S. R. Gold-Veerkamp, C. Abke, J. and Borgeest, K. A new didactic method for programming in $\mathrm{C}$ for freshmen students using LEGO mindstorms EV3. International Confer- 
ence on Interactive Collaborative Learning (ICL), 2015, pp. 911-914. https://doi.org/ $10.1109 / \mathrm{icl} .2015 .7318148$

[2] Brandt, A. M., \& Colton, M. B. (2008, March). Toys in the classroom: LEGO MindStorms as an educational haptics platform. In 2008 symposium on haptic interfaces for virtual environment and teleoperator systems IEEE, pp. 389-395. https://doi.org/10.1109/ haptics.2008.4479982

[3] Ortega, G. C., Téllez, A. F., Guarnizo, J. G., and Camacho, E. C. (2021). Educational Environment for Primary School Using a Commercial Robotic System. Ingeniería, 26(1): 4161.

[4] Roussou, M. (2004). Learning by doing and learning through play: an exploration of interactivity in virtual environments for children. Computers in Entertainment (CIE), 2(1): 1010. https://doi.org/10.1145/973801.973818

[5] Samuelsson, I. P., \& Carlsson, M. A. (2008). The playing learning child: Towards a pedagogy of early childhood. Scandinavian journal of educational research, 52(6); 623-641. https://doi.org/10.1080/00313830802497265

[6] Broadhead, P. (2006). Developing an understanding of young children's learning through play: the place of observation, interaction and reflection. British Educational Research Journal, 32(2): 191-207. https://doi.org/10.1080/01411920600568976

[7] Seraj, M., Katterfeldt, E. S., Bub, K., Autexier, S., \& Drechsler, R. (2019, November). Scratch and Google Blockly: How Girls' Programming Skills and Attitudes are Influenced. In Proceedings of the $19^{\text {th }}$ Koli Calling International Conference on Computing Education Research, pp. 1-10. https://doi.org/10.1145/3364510.3364515

[8] Maiti, A., Maxwell, A. D., Kist, A. A., \& Orwin, L. (2014). Merging remote laboratories and enquiry-based learning for STEM education. International Journal of Online Engineering (iJOE), 10(6): 50-57. https://doi.org/10.3991/ijoe.v10i6.3997

[9] Zygouris, N. C., Striftou, A., Dadaliaris, A. N., Stamoulis, G. I., Xenakis, A. C., \& Vavougios, D. (2017, April). The use of LEGO mindstorms in elementary schools. In 2017 IEEE Global Engineering Education Conference (EDUCON), IEEE, pp. 514-516. https://doi.org/10.1109/EDUCON.2017.7942895

[10] Gabriele, L., Marocco, D., Bertacchini, F., Pantano, P., \& Bilotta, E. (2017). An Educational Robotics Lab to Investigate Cognitive Strategies and to Foster Learning in an Arts and Humanities Course Degree. International Journal of Online Engineering (iJOE), 13(4): 7-19. https://doi.org/10.3991/ijoe.v13i04.6962

[11] Brace, J. and Koblentz, E. (2016). 2016 Holiday Gift Guide. IEEE Spectrum, 53(12): 2223.

[12] Moreira, F., Sousa, R. M., Leão, C. P., Alves, A. C., \& Lima, R. M. (2009). Measurement rounding errors in an assessment model of project led engineering education. International Journal of Online Engineering (iJOE), 5: 39-44. https://doi.org/10.3991/ijoe.v5i6.1092

[13] Bricks 4 Kidz ${ }^{\circledR}$ [online]. Available: https://www.bricks4kidzsaudiarabia.com/ (Accessed on: 2 August, 2021).

[14] FIRST LEGO LEAGUE [online]. Available: http://fllsaudi.com/en_US/ (Accessed on: 2 August, 2021).

[15] Robot club in ALQatif [online]. Available: https://www.robot-club.org/ (Accessed on: 3 August, 2021).

[16] Arabic robot center [online]. Available: http://robotarab.com/ (Accessed on: 3 August, 2021).

[17] Valdez, F., Castillo, O., Caraveo, C., \& Peraza, C. (2021). Comparative Study of Conventional and Interval Type-2 Fuzzy Logic Controllers for Velocity Regulation in Lego Mindstorms Ev3 Humanoids. Toward Humanoid Robots: The Role of Fuzzy Sets: A Handbook on Theory and Applications, pp. 201-219. https://doi.org/10.1007/978-3-030-67163-1_7 
[18] Chaudhary, V., Agrawal, V., \& Sureka, A. (2016). An experimental study on the learning outcome of teaching elementary level children using Lego Mindstorms EV3 robotics education kit. arXiv preprint arXiv:1610.09610.

[19] ÜÇGÜL, M. (2013). History and educational potential of Lego Mindstorms NXT. Mersin Üniversitesi Eğitim Fakültesi Dergisi, 9(2): 127-137.

[20] García-Peñalvo, F. J., Rees, A. M., Hughes, J., Jormanainen, I., Toivonen, T., \& Vermeersch, J. (2016, November). A survey of resources for introducing coding into schools. In Proceedings of the Fourth International Conference on Technological Ecosystems for Enhancing Multiculturality, pp. 19-26. https://doi.org/10.1145/3012430.3012491

[21] Afari, E., \& Khine, M. S. (2017). Robotics as an educational tool: impact of lego mindstorms. International Journal of Information and Education Technology, 7(6): 437-442. http://dx.doi.org/10.18178/ijiet.2017.7.6.908

[22] Barnes, D. J. (2002, February). Teaching introductory Java through LEGO MINDSTORMS models. In Proceedings of the 33rd SIGCSE technical symposium on Computer science education, 2002, pp. 147-151. https://doi.org/10.1145/563340.563397

[23] Kim, S. H., \& Jeon, J. W. (2008). Introduction for freshmen to embedded systems using LEGO Mindstorms. IEEE Transactions on Education, 52(1): 99-108. https://doi.org/ 10.1109/TE.2008.919809

[24] Kim, S. H., \& Jeon, J. W. (2006, May). Educating C language using LEGO Mindstorms robotic invention system 2.0. In Proceedings 2006 IEEE International Conference on Robotics and Automation (ICRA), IEEE, 2006, pp. 715-720. https://doi.org/10.1109/robot. 2006.1641794

[25] Haak, V., Abke, J., \& Borgeest, K. (2018, April). Conception of a Lego Mindstorms EV3 simulation for teaching $\mathrm{C}$ in computer science courses. In 2018 IEEE global engineering education conference (EDUCON), 2018, pp. 478-483. https://doi.org/10.1109/educon. 2018.8363269

[26] Ahmed, S., Shaikh, A., Alshahrani, H., Alghamdi, A., Alrizq, M., Baber, J., \& Bakhtyar, M. (2021). Transfer Learning Approach for Classification of Histopathology Whole Slide Images. Sensors, 21(16), 5361. https://doi.org/10.3390/s21165361

[27] Naveed, Q. N., Qureshi, M. R. N., Tairan, N., Mohammad, A., Shaikh, A., Alsayed, A. O., ... \& Alotaibi, F. M. (2020). Evaluating critical success factors in implementing E-learning system using multi-criteria decision-making. Plos one, 15(5), e0231465. https://doi.org/10. 1371/journal.pone.0231465

\section{$7 \quad$ Authors}

Khawla Nasser AlQarzaie is a lecturer in the Department of Computer Science, College of Computer, Qassim University. She holds a Master's Degree in Informatics. She was graduated from the Computer Science Department, College of Computer, Qassim University, Saudi Arabia.

Sara Awadh AlEnezi is a lecturer in the Department of Cyber Security at Buradiah Private Colleges. She holds a Master's Degree in Informatics. She was graduated from the Computer Science Department, College of Computer, Qassim University, Saudi Arabia (Email: sar19-90@hotmail.com).

Article submitted 2021-10-12. Resubmitted 2021-11-27. Final acceptance 2021-11-29. Final version published as submitted by the authors. 